園学雑. (J. Japan. Soc. Hort. Sci.) 66 (1)：141-147. 1997.

\title{
ファレノプシスの生育・開花に及ぼす養分欠乏の影響と その症状について
}

\author{
米田和夫 · 臼井真理子* ·窪田 聡 $* *$ \\ 日本大学生物資源科学部 252 藤沢市亀井野 1866 \\ *(獭ミヨシ八ヶ岳㖘場 409-16 北巨摩郡小淵沢町上笹尾 \\ **蜄林水産省野菜・茶業試験場 514-23 安芸郡安濃町草生
}

Effect of Nutrient Deficiency on Growth and Flowering of Phalaenopsis

Kazuo Yoneda, Mariko Usui ${ }^{*}$ and Satoshi Kubota**

Coll. Bioresource Sci., Nihon Univ., 1866 Kameino, Fujisawa Kanagawa 252

Miyoshi Co. Ltd., Yatsugatake Farm, Kobuchizawa, Kitakoma, Yamanashi 409-16

Natl. Res. Inst. of Veg., Omam. Plants \& Tea, Annou, Aki, Mie 514-23

\begin{abstract}
Summary
The effects of N, P, K and Mg on the growth and flowering of Phalaenopsis were investigated.

1. When no nitrogen was supplied, the number and size of fully developed leaves was reduced and defoliation increased, resulting in considerable reduction of total leaf area. The concentration of chlorophyll decreased but no decrease in the number of flower stalks occurred. Roots showed no visible changes, but the total plant dry weight was lighter compared with plants supplied nitrogen.

2. In -P plants, defoliation increased and the production of new ones was curtailed. Phosphorus deficiency induced purple and red coloration of the older leaves, leaf distortion and curling of the leaf apices. Yellowing of an incividual leaf began from its apex and gradually spreaded basipetally to the entire leaf, ending in defoliation. The deficiency symptoms spread upward from the basal leaves of a plant. The area of newly developed leaves was reduced and plant growth was stunted. The dry weight of the plants was also reduced and new roots were not produced. The production of flower stalks was almost completely inhibited.

3. No significant difference in new leaf formation or defoliation was observed among plants supplied or denied potassium. However, the surface area of fully developed leaves tended to become smaller in plants lacking potassium. The production of flower stalks was not affected, but flower stalks tended to develop rather early. Leaves and roots showed no noticeable symptoms of potassium deficiency.

4. Calcium deficiency produced no noticeable change in plant growth and/or production of flower stalks.

5. No noticeable symptoms of magnesium deficiency were observed, but the development of flower stalks was delayed slightly in comparison to the control.
\end{abstract}

\section{緒言 \\ ファレノプシスの施肥に関する報告は比較的以前か らある（遠藤・杉，1992；位田ら，1995；寉田ら， 1990; 寉田・米田, 1993a; Poole · Seeley, 1978;}

1996 年 7 月 3 日 受付. 1996 年 9 月 27 日 受理.
Sheehan, 1961; 田中ら，1988）。しかしながら生育に 好適といわれる坴素湢度は $50 \mathrm{ppm} \sim 1000 \mathrm{ppm}$ の範囲 であり，最適施肥水準としてはあまりにも範曲が広い。 この原因として，培地の種類，灌水・施肥方法，温度 や光管理方法，品種などの違いが考えられる．このう ち培地の種類についてはミズゴケを用いた場合の灌水 
・施肥方法の違いによる培地内養分の動態についても 比較的明らかにされている（須藤・篠田，1990; 須藤 ら，1991)。また温度や光管理方法は近年平準化して いるものの, 環境と施肥との相互関係について検討し た報告は多くない.さらに施肥の品種間差についても 同様である。

本論文はファレノプシスの光合成，生育・開花に及 ぼす N, P, K, Ca，Mg 欠その影響，ならびにその欠そ症 状について検討した。

\section{材料および方法}

供試材料は Phalaenopsis Musashino '90' $\times$ Phal. Hakalau Queen 'America' の播種後 3 年（フラスコ出 し後 1 年）の未開花株を 3 号プラスチックポットにミ

Table 1. Component of nutrient solution in each treatment.

\begin{tabular}{|c|c|c|c|c|c|}
\hline \multirow{2}{*}{ Element } & \multicolumn{5}{|c|}{ Concentration (mM) } \\
\hline & Full & $-\mathrm{N}$ & $-P$ & $-\mathrm{K}$ & $-M g$ \\
\hline$N$ & 15.00 & 0.00 & 15.00 & 15.00 & 15.00 \\
\hline$P$ & 1.00 & 1.00 & 0.00 & 1.00 & 1.00 \\
\hline K & 10.01 & 10.01 & 10.01 & 0.00 & 10.01 \\
\hline $\mathrm{Ca}$ & 2.32 & 2.32 & 2.32 & 2.32 & 2.32 \\
\hline $\mathrm{Mg}$ & 2.50 & 2.50 & 2.50 & 2.50 & 0.00 \\
\hline$S$ & 2.76 & 2.76 & 2.76 & 2.76 & 2.76 \\
\hline $\mathrm{Na}$ & 2.16 & 1.16 & 1.16 & 12.16 & 7.16 \\
\hline $\mathrm{Cl}$ & 0.64 & 11.14 & 0.64 & 0.64 & 0.64 \\
\hline $\mathrm{Fe}$ & 0.10 & 0.10 & 0.10 & 0.10 & 0.10 \\
\hline $\mathrm{Mn}$ & 0.15 & 0.15 & 0.15 & 0.15 & 0.15 \\
\hline $\mathrm{Zn}$ & 0.10 & 0.10 & 0.03 & 0.03 & 0.03 \\
\hline $\mathrm{Cu}$ & $1 \times 10^{-4}$ & $1 \times 10^{-4}$ & $1 \times 10^{-4}$ & $1 \times 10^{-4}$ & $1 \times 10^{-4}$ \\
\hline Co & $1 \times 10^{-4}$ & $1 \times 10^{-4}$ & $1 \times 10^{-4}$ & $1 \times 10^{-4}$ & $1 \times 10^{-4}$ \\
\hline I & $1 \times 10^{-4}$ & $1 \times 10^{-4}$ & $5 \times 10^{-3}$ & $5 \times 10^{-3}$ & $5 \times 10^{-3}$ \\
\hline Mo & $1 \times 10^{-3}$ & $1 \times 10^{-3}$ & $1 \times 10^{-3}$ & $1 \times 10^{-3}$ & $1 \times 10^{-3}$ \\
\hline B & 0.10 & 0.10 & 0.10 & 0.10 & 0.10 \\
\hline EDTA & 0.10 & 0.10 & 0.10 & 0.10 & 0.10 \\
\hline
\end{tabular}

ズゴケ植えしたものを用いた，栽培管理方法は夏期の 強光時に寒冷紗を用いて $60 \%$ 遮光した温室内に 2 日

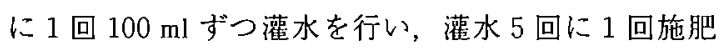

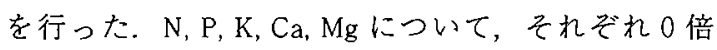
(欠之区) と 1 倍 (对照区) の濃度区を設けた（第 1 表). 施肥は 1994 年 8 月から 1995 年 1 月まで計 18 回 行い, 生育調查は 1 ケ月ごとに行った。光合成は昼間 液間を $30{ }^{\circ} \mathrm{C} / 22{ }^{\circ} \mathrm{C}$, 湿度 $70 \%$, 光強度 $300 \mu$ $\mathrm{mol} \cdot \mathrm{m}^{-2} \cdot \mathrm{s}^{-1}, 12$ 時間日長に設定したファイトトロン に移し，順化した株の上位葉から第 2 葉に光合成ポロ メーター（KIP-9010, 小糸工業竹) を取り付け，流 速約 $500 \mathrm{ml} \cdot \mathrm{min}^{-1}$ の空気を送り, $\mathrm{CO}_{2}$ 吸収速度を 10 分ごとに2日間連続して測定した。

養分含有率はファイトトロンに移した株の中から 5 株を用い，葉部，茥部，根部の部位ごとに分別採取し た試料について湿式分解後，Nはケルダール法，Pは モリブデン青法, $\mathrm{K}, \mathrm{Ca}$ と $\mathrm{Mg}$ は原子吸光法により測 定した.

\section{結果および考察}

これまで生育・開花に及ぼす窒素，リン，カリウム などの個々の盖分の影滰とその最適水準について検討 されたものは少ない(Poole・Seeley, 1978). また盖分 の久そあるいは過剩などの生理障害がファレノプシス にどのような症状を呈するかについては十分に明らか にされていないがこの実験により次のようなことが 明らかになった。

\section{1. 窒 素}

空素が久そすると展開葉数が少なくなり，落葉数が やや多くなった（第 2 表）。また下位葉には時間の経 過とともにクロロシスが起こり，窒素の欠乏症状が顕 著に現れた（第 1 図 B)．展開葉面積も小さく，さら に 1 枚あたりの面積も小さくなった。根の生育はほと

Table 2. Effects of N, P, K and Mg deficiency on growth and flower stalk formation in Phalaenopsis.

\begin{tabular}{|c|c|c|c|c|c|c|c|c|c|c|}
\hline \multirow{2}{*}{ Plot } & \multicolumn{2}{|c|}{ Number of leaves } & \multicolumn{2}{|c|}{ Area of leaves } & \multicolumn{2}{|c|}{ Roots } & \multirow{2}{*}{$\begin{array}{l}\text { Dry } \\
\text { matter } \\
(\mathrm{g} / \text { plant })\end{array}$} & \multirow{2}{*}{$\begin{array}{l}\text { Relative } \\
\text { conc. of } \\
\text { chlorophyll } \\
(\text { SPAD) }\end{array}$} & \multicolumn{2}{|c|}{ Average of flower stalk } \\
\hline & Expanded & Defoliated & $\left(\mathrm{cm}^{2} / \mathrm{plant}\right)$ & $\left(\mathrm{cm}^{2} /\right.$ leaf $)$ & Number & $\begin{array}{c}\text { Weight } \\
\text { (g/plant) }\end{array}$ & & & $\begin{array}{c}\text { Formation } \\
(\%)\end{array}$ & $\begin{array}{c}\text { Emergence } \\
\text { date }\end{array}$ \\
\hline Full (Control) $)^{y}$ & $3.1 a^{x}$ & $3.2 \mathrm{a}$ & $237.7 \mathrm{a}$ & $63.9 \mathrm{a}$ & $54.2 \mathrm{a}$ & $38.5 \mathrm{a}$ & $6.06 \mathrm{a}$ & $36.8 \mathrm{~b}$ & 64.0 & 21 Dec. \\
\hline $\mathrm{N}$ deficiency $(-\mathrm{N})$ & $2.2 \mathrm{~b}$ & $3.7 \mathrm{a}$ & $163.6 \mathrm{~b}$ & $44.7 \mathrm{~b}$ & $51.2 \mathrm{a}$ & $35.3 \mathrm{a}$ & $4.12 b$ & $26.0 \mathrm{c}$ & 70.8 & 21 Dec. \\
\hline$P$ deficiency $(-P)$ & $2.4 \mathrm{~b}$ & $4.9 \mathrm{a}$ & $179.0 \mathrm{~b}$ & $34.2 \mathrm{~b}$ & $45.0 \mathrm{~b}$ & $29.1 \mathrm{~b}$ & $3.40 \mathrm{~b}$ & $38.3 \mathrm{a}$ & 4.0 & 26 Dec. \\
\hline$K$ deficiency $(-K)$ & $3.0 \mathrm{a}$ & $2.3 \mathrm{a}$ & $209.4 \mathrm{~b}$ & $60.6 a$ & $61.8 \mathrm{a}$ & $43.3 \mathrm{a}$ & $5.87 a$ & $38.6 \mathrm{a}$ & 64.0 & 11 Dec. \\
\hline $\mathrm{Mg}$ deficiency $(-\mathrm{Mg})$ & $2.8 \mathrm{~b}$ & $2.8 \mathrm{a}$ & $227.6 \mathrm{a}$ & $66.2 \mathrm{a}$ & $56.0 \mathrm{a}$ & $39.4 a$ & $5.93 a$ & $35.7 \mathrm{~b}$ & 60.0 & $16 \mathrm{Jan}$. \\
\hline
\end{tabular}

$z$ The value are measured by chlorophyll meter SPAD-502 (Minolta).

" Component of nutrient solution are shown in Table 1.

$\times$ Different letter within columns represent significant difference $(p<0.05)$. 


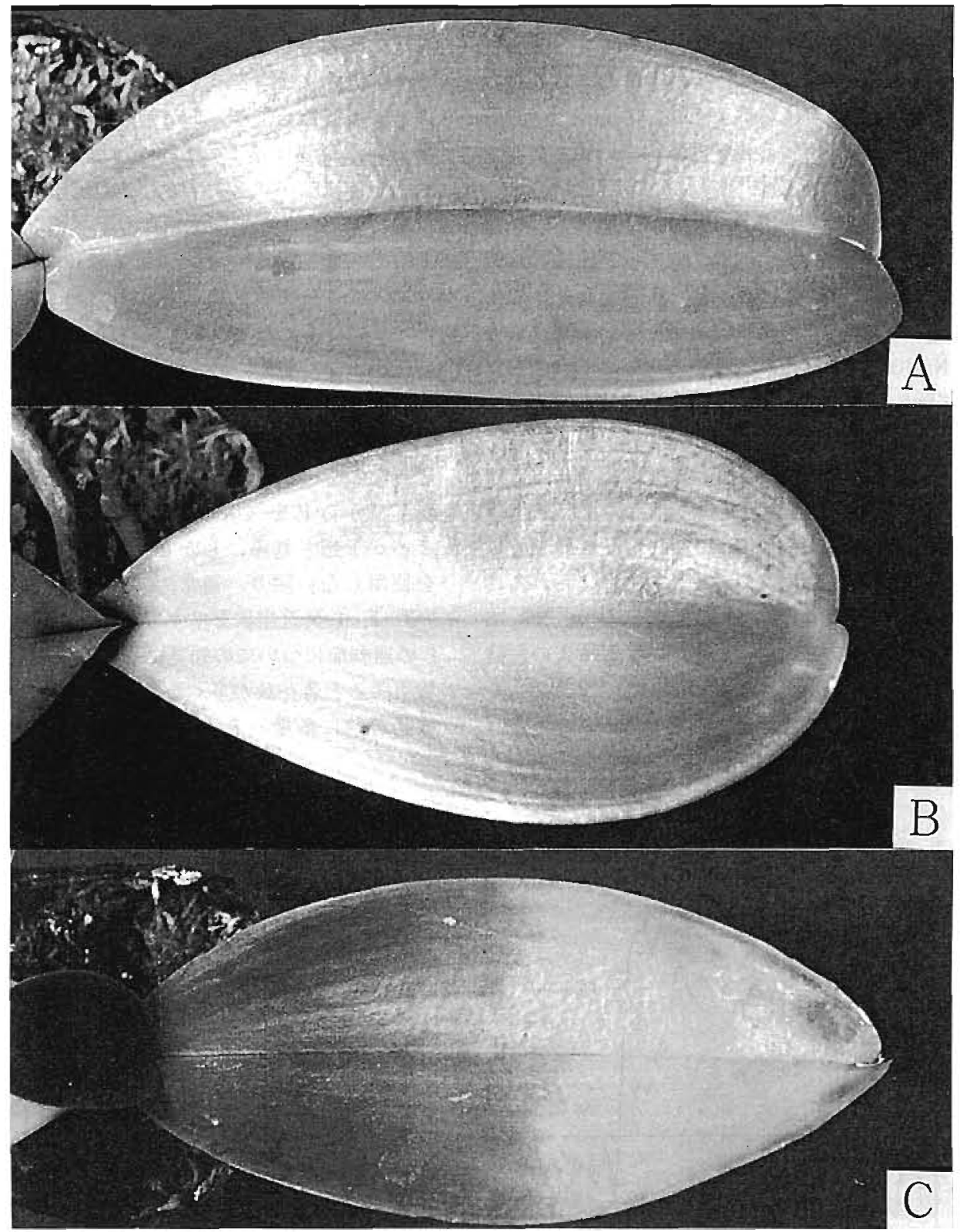

Fig. 1. Symptoms of nitrogen and phosphorus deficiency in second leaf from the top in Phalaenopsis. The symptom of nitrogen deficiency was a marked decrease on the concentration of chrolophyll from the leaf $(B)$, and that of phosphorus deficiency was coloration to purple and red makings from the leaf end (C). (A) showed the 2 nd leaf from the top of leaf of full concentration.

んど影䄽されなかった（第 2 表）が, $\mathrm{CO}_{2}$ 吸収速度が 大きく低下し(第 2 図)，乾物生量は明ら加少な くなった。また葉緑素濃度は明らかに低下した（第 2 表).しかし花茥発生に影響は認められなかった。こ れまでの研究では花荎は $\mathrm{N}$ 施用量を少なくするか,
花萃誘導の少なくとも1ケ月くらい前に打ち切ること により発生時期が早まる（米田ら，1984; 筀田・米田， 1993 a). すなわち $\mathrm{N}$ 欠忌に陷って生育が明らがに不 良になっていても花菱は発生するが，花茎長は短く， 小花数は少ない。逆に $\mathrm{N}$ を多く施用したり, 普通栽 
培で 10 月頃まで $\mathrm{N}$ 施肥を継続すると, 花茎発生は遅 机る傾向にあることが明らかになっているが，本実験 での花茎発生に対する $\mathrm{N}$ 欠乏の影響はこれを熟付け るものである。

$\mathrm{N}$ の場合，特に施用する化学的形態が問題となる. 生育・開花に及ぼす無機態 $\mathrm{N} の$ 形態の影響について, 温室栽培の苗（田中ら，1986）とフラスコ苗 (Hinnen ら，1989; 鈴木・米田，1994）で検討されて いる.これらによれば， $\mathrm{NH}_{4}-\mathrm{N} か ゙$ 増加すると根の生 育は抑制されることは両報告で共通しているが，最適 な $\mathrm{NH}_{4}-\mathrm{N}: \mathrm{NO}_{3}-\mathrm{N}$ 比は異なっている. しかしながらつ アレノプシスは着生ランであり，生息環境は明らかに 酸化的な条件にあること，また温室条件ではミズゴケ の分解にともない $\mathrm{N}$ は $\mathrm{NH}_{4}$-N として供給されること， さらにミズゴケ中の無機態 N は施用した肥料とほぼ 同じ比率で可溶化され（窒田，1994），一般の土堙に 比ベてミズゴケの硝酸化成活性が低いと考えられるこ とから， $\mathrm{NH}_{4}-\mathrm{N}$ を特に多くする必要はなく, $\mathrm{NO}_{3}-\mathrm{N}$ を主体に施用した方が $\mathrm{NH}_{4}-\mathrm{N}$ 過剩による障害の危険 性は少ない。このことから $\mathrm{NH}_{4}-\mathrm{N}: \mathrm{NO}_{3}-\mathrm{N}$ 比は（0: 100）－（30:70）の範囲が妥当と考えられる.

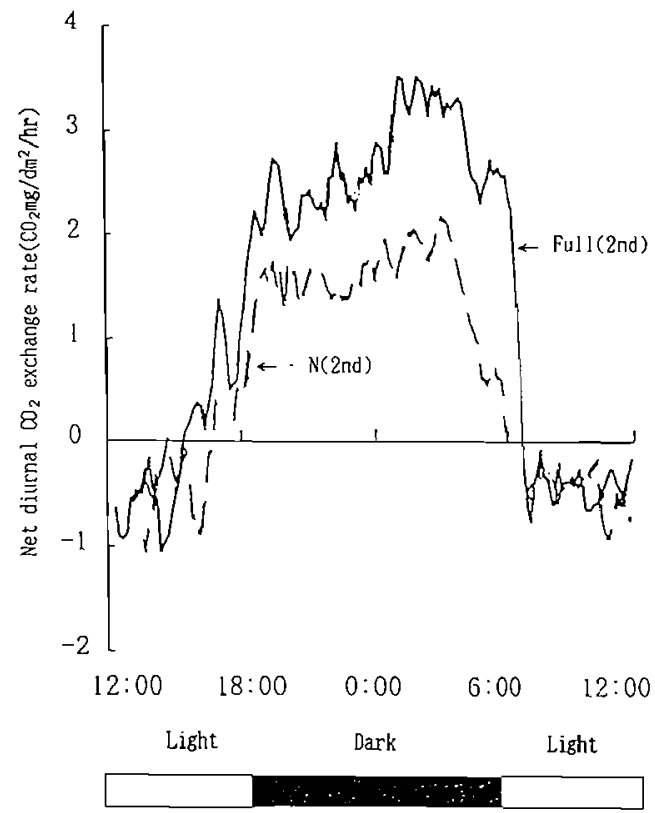

Fig. 2. Effects of nitrogen deficiency on net diurnal $\mathrm{CO}_{2}$ exchange rates in Phalamopsis after 120 days treatment.

Condition of measurements: $30{ }^{\circ} \mathrm{C} / 20{ }^{\circ} \mathrm{C}$ (day/ night). $300 \mu \mathrm{mol} / \mathrm{m}^{2} / \mathrm{s}$ during the day (12 hr).
2.リン

P が欠そすると展開葉数が少なく，落葉数が多くな る. 欠乏症状は最初に下位葉がアントシアンの生成に

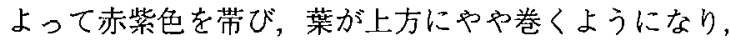
葉先から黄変が始まって（第1図 C), ついにはそれ が葉全体に広がり落葉する。この現象は下位葉から順 に進行する．また展開葉面積も小さくなり，特に 1 枚 あたりの葉面積が小さい(第 2 表). $\mathrm{CO}_{2}$ 吸収速度は $\mathrm{P}$ 欠乏によって著しく低下するため（第 3 図），乾物 生産量は少なくなる. 根の先端部分は枯死して, 新し い根が出なくなるため，根数が少なくなり，根重も軽 くなる．また花茎の発生は強く阻害された。

こうしな症状は $\mathrm{P}$ 施用を止めてから3ヶ月ほど経 過したのちに発生したことから推察すると, 症状が発 現してからPを施用しても十分な回復は見込めない ことが予想される。しかし特にP 固定の大きい培地 を使用しない限り，通常のPを含む肥料を施用して いれば，P攵乏症状を呈することはないと思われるし， Pの過剩症についての知見はない，一般的にPを多く 施用すると着花数が多くなるといわれているため，花 萃誘導前に多量のPを施用することが生産者の間で

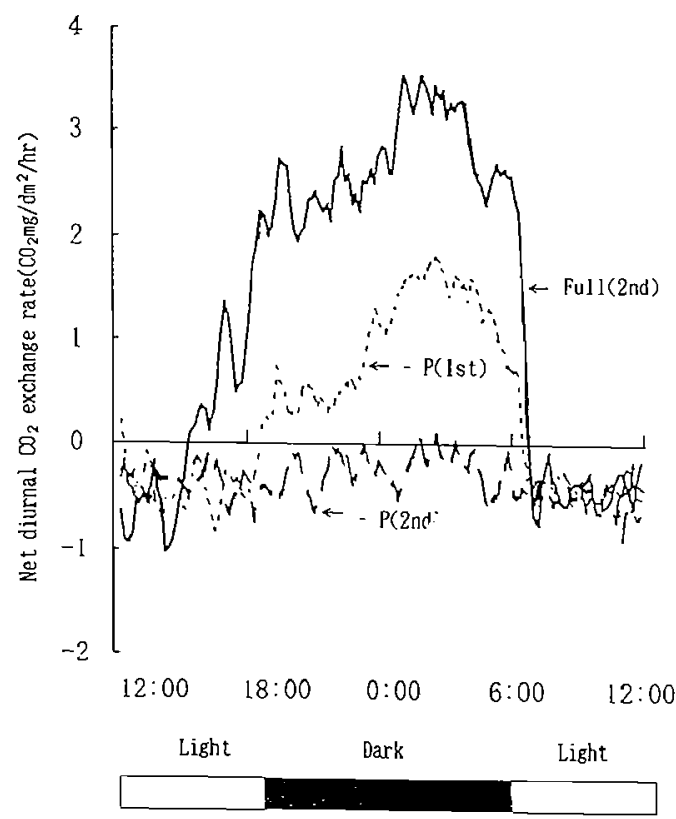

Fig. 3. Effects of phosphorus deficiency on net diurnal $\mathrm{CO}_{2}$ exchange rates in Phalaenopsis after 120 days treatment.

Condition of measurements: $30{ }^{\circ} \mathrm{C} / 20{ }^{\circ} \mathrm{C}$ (day/ night). $300 \mu \mathrm{mol} / \mathrm{m}^{2} / \mathrm{s}$ during the day (12 hr). 
Table 3. Effects of N, P, K and Mg deficiency on nutrient contents in total dried plants parts of Phalaenopsis.

\begin{tabular}{|c|c|c|c|c|c|c|}
\hline Portion & Plot & $N(\%)$ & $\mathrm{P}(\%)$ & $K(\%)$ & $\mathrm{Ca}(\%)$ & $\mathrm{Mg}(\%)$ \\
\hline \multirow{5}{*}{ Leaf } & Full $^{z}$ & $1.00 \mathrm{a}^{\mathrm{y}}$ & $0.13 \mathrm{~b}$ & $5.33 a$ & $1.35 \mathrm{ab}$ & $0.82 \mathrm{ab}$ \\
\hline & $-N$ & $0.78 b$ & $0.20 \mathrm{a}$ & $5.84 \mathrm{a}$ & $1.52 \mathrm{a}$ & $1.03 a$ \\
\hline & $-\mathrm{P}$ & $1.30 \mathrm{a}$ & $0.08 \mathrm{c}$ & $7.07 \mathrm{a}$ & $1.41 \mathrm{a}$ & $0.94 \mathrm{a}$ \\
\hline & $-\mathrm{K}$ & $1.05 \mathrm{a}$ & $0.16 \mathrm{a}$ & $1.83 c$ & $1.46 \mathrm{a}$ & $1.16 \mathrm{a}$ \\
\hline & $-\mathrm{Mg}$ & $0.94 \mathrm{a}$ & $0.14 \mathrm{a}$ & $7.48 \mathrm{a}$ & $1.34 \mathrm{a}$ & $0.62 c$ \\
\hline \multirow{5}{*}{ Stem } & Full & $1.24 \mathrm{a}$ & $0.22 \mathrm{a}$ & $1.80 \mathrm{a}$ & $0.64 \mathrm{a}$ & $0.68 \mathrm{a}$ \\
\hline & $-N$ & $0.85 b$ & $0.21 \mathrm{a}$ & $1.82 \mathrm{a}$ & $0.61 \mathrm{a}$ & $0.66 \mathrm{a}$ \\
\hline & $-\mathrm{P}$ & $1.23 \mathrm{a}$ & $0.09 \mathrm{c}$ & $3.03 \mathrm{a}$ & $0.77 \mathrm{a}$ & $0.95 \mathrm{a}$ \\
\hline & $-\mathrm{K}$ & $1.22 \mathrm{a}$ & $0.26 \mathrm{a}$ & $0.68 \mathrm{~b}$ & $0.69 \mathrm{a}$ & $0.76 \mathrm{ab}$ \\
\hline & $-\mathrm{Mg}$ & $1.24 \mathrm{a}$ & $0.25 \mathrm{a}$ & $3.84 a$ & $0.80 \mathrm{a}$ & $0.52 \mathrm{c}$ \\
\hline \multirow{5}{*}{ Root } & Full & $1.12 \mathrm{a}$ & $0.21 \mathrm{ab}$ & $1.87 a$ & $1.05 b$ & $0.61 \mathrm{a}$ \\
\hline & $-N$ & $0.63 b$ & $0.24 \mathrm{a}$ & $2.18 \mathrm{a}$ & $1.16 \mathrm{a}$ & $0.76 \mathrm{a}$ \\
\hline & $-P$ & $1.57 \mathrm{a}$ & $0.09 \mathrm{c}$ & $2.15 \mathrm{a}$ & $1.05 \mathrm{a}$ & $0.66 \mathrm{a}$ \\
\hline & $-\mathrm{K}$ & $1.34 \mathrm{a}$ & $0.20 \mathrm{~b}$ & $1.08 \mathrm{~b}$ & $1.25 \mathrm{a}$ & $0.73 a$ \\
\hline & $-M g$ & $1.22 \mathrm{a}$ & $0.20 \mathrm{~b}$ & $3.06 \mathrm{a}$ & $1.07 \mathrm{a}$ & $0.38 \mathrm{c}$ \\
\hline \multirow{5}{*}{ Total } & Full & $1.09 \mathrm{~b}$ & $0.18 \mathrm{~b}$ & $3.19 \mathrm{a}$ & $0.97 \mathrm{a}$ & $0.73 b$ \\
\hline & $-N$ & $0.69 \mathrm{c}$ & $0.21 \mathrm{a}$ & $2.91 \mathrm{a}$ & $0.90 \mathrm{ab}$ & $0.77 \mathrm{a}$ \\
\hline & $-P$ & $1.45 \mathrm{a}$ & $0.09 \mathrm{c}$ & $4.08 \mathrm{a}$ & $0.99 a$ & $0.91 \mathrm{a}$ \\
\hline & $-\mathrm{K}$ & $1.23 \mathrm{a}$ & $0.22 \mathrm{a}$ & $1.09 c$ & $1.00 \mathrm{a}$ & $0.88 \mathrm{a}$ \\
\hline & $-\mathrm{Mg}$ & $1.13 \mathrm{a}$ & $0.20 \mathrm{a}$ & $5.01 \mathrm{a}$ & $1.02 \mathrm{a}$ & $0.53 c$ \\
\hline
\end{tabular}

2 Component of nutrient solution are shown in Table 1.

y Different letter within columns represent significant difference $(p<0.05)$.

行われている。しかし現時点では高濃度のP を施用 したときの開花反応への影製は十分に明かにされてい ない.

ファレノプシスのP P含有率は他の盖分と比較して 最も低く，その要求量は少ない(第 3 表).このこと から栄盖生長期間中は必ずしも高濃度のP 施用す る必要はない（田中・井上，1987）と思われるが，低 濃度でも継続的にPを供給することは必要であろう。

\section{3. カリウム}

$\mathrm{K}$ の欠之条件では展開葉数と落葉数は完全培盖液と 变わらないが，展開葉面積がやや小さくなる傾向にあ る. 根の生育に対しても $\mathrm{K}$ 欠乏の影留はみられなか った（第 2 表）. $\mathrm{CO}_{2}$ 吸収速度は完全培盖液のものに 比へ，明期後半からの吸収が減少し（第 4 図）, 最大 速度も低下して，乾物生産量はやや小さくなる傾向が みられた。また葉や根などに視認できる欠乏症状は発 現しなかった，花荎発生は $\mathrm{K}$ 欠乏の影翠はみられな いが，発生時期が早くなる傾向がみられた。

ミズゴケには比較的多くのKが含まれるため（篗 田・米田, 1993 b)，これが供給源となって久之症状 が発現しなかったものと考えられるが，フラスコ苗を

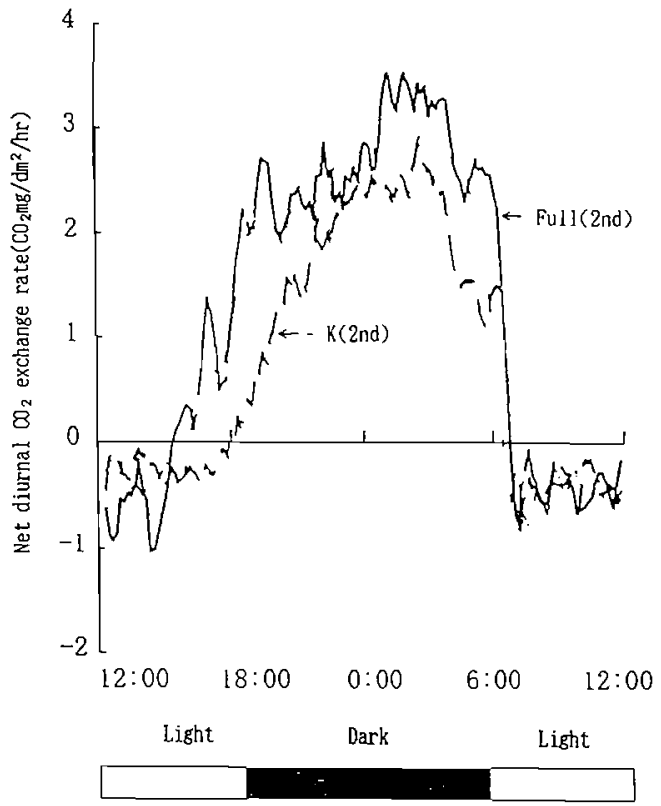

Fig. 4. Effects of potassium deficiency on net diurnal $\mathrm{CO}_{2}$ exchange rates in Phalaenopsis after 120 days treatment.

Condition of measurements: $30{ }^{\circ} \mathrm{C} / 20{ }^{\circ} \mathrm{C}$ (day/ night). $300 \mu \mathrm{mol} / \mathrm{m}^{2} / \mathrm{s}$ during the day $(12 \mathrm{hr}$ ). 
$\mathrm{K}$ 欠乏培地で培養した場合でも，明確な欠乏症状の発 現は認められていない（鈴木，1995）.

\section{4.カルシウム}

温室栽培条件で，生育に及ぼす $\mathrm{Ca}$ の影響について 検討されたものはないが, フラスコ苗への影帮につい て検討した報告はある．段ら（1993）はCaがなくて もフラスコ苗は生育するとしているが，鈴木（1995） によれば，Ca 欠そで培養した一部の苗に展開中の葉 や根の先端が枯死する現象を観察し，また一見正常に 生育した苗でも，これを温室に植え出すと落葉が多く なり，生育が停止することが認められている，花荎発 生に及ぼす Ca の影響は明瞭ではなかった。

\section{5.マグネシウム}

展開葉数がやや少なくなる他は, 展開葉面積, 根の 発育, 乾物生産ともに完全培養液区と遜色なかった。 花茎発生には差がみられないが, 花茎発生時期が明ら かに遅くなった (第 2 表)。しかし特に久之症とみら れる症状は発現しなかった。一方フラスコ苗を $\mathrm{Mg}$ 欠 㞯培地で培養すると下位葉の周辺部から徐々に黄白色 化し，時間の経過とともにその部分が枯れ込む現象が みられる（鈴木，1995）ことが報告されているが, $\mathrm{Mg}$ の過剩症に関する知見はない，一般に，Mgは高 濃度による生育阻害作用が比較的強い養分として知ら れていることから(嶋田，1989），Mgを高濃度に施 用する必要はないと考えられる。

以上，生育・開花にかかわる養分の影響とその久そ 症について, 植物が利用する養分は培地内の溶液から 供給されるので施肥蕽度よりはむしろ供給回数，すな わち盖分の量と水の量で決まる培地内溶液濃度が重要 である，すでに培地内溶液の制御方法は明らかにされ ている（筀田，1994）ので生育に好適な水分状態のも とで生育・開花に及ほす溶液濃度の影響について濃度 段階を变えて詳細に検討することが必要である。また 養分濃度や供給量が生育と花茎発生に及ほす影暃を検 討した例は比較的多いが, 花荎の伸長や小花数などの 着花・開花に及ぼす各盖分の影響についての知見は少 ない。つほみや小花はその他の器官に比べて㪈分含有 率が高い特徵が認められて扔り (Kubota・Yoneda, 1993），生殖生長期間中にはそれらの養分要求性が高 くなることは十分に予測される，実際栽培でも $\mathrm{P} や$ $\mathrm{K}$ を花茎誘導の開始前後から多く与えている. しかし 着花・開花からみた肥料の施用時期や量は必ずしも明 確でなく, 今後つぼみや小花への養分の転流と吸収量 との関係を含めた検討が重要となろう。また実際の栽
培では欠そ症よりはむしろ肥料の過剩施用によるとみ られる葉の異常な权じれなどの生育障害が発生してお $り$ ，各養分の過剩症に関する知見の蓄積も検討する必 要があると考えられる。

\section{摘 要}

ファレノプシスの各盖分の生育・開花への影響，な らびにそれの欠乏症について検討した。

1.Nが久そるると展開葉数が少なくなり，落葉数が やや多くなった，展開葉面積も小さく，さらに 1 枚あ たりの面積も小さくなった。また葉緑素濃度は明らか に低下した。しかし花茥発生に影響は認められなかっ た。根の生青はほとんど影響されないが，乾物生産量 は明らかに少なくなった。

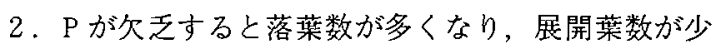
なく，欠乏症状は下位葉が最初に赤紫色を帯びて葉が 上方にやや巻くようになり，葉先から黄変が始まって， 葉全体に広がり，ついには落葉した。この現象は下位 葉から順に進行した。また新葉の 1 枚あたりの葉面積 が小さく展開葉面積も小さくなって, 乾物生産量は少 なくなった，根の先端部分は枯死して, 新根が再生し ないため根数が少なく, 根重も軽くなり，花茎の発生 は強く阻害された。

3. $\mathrm{K}$ 欠乏は展開葉数と落葉数は完全培盖液区と変わ らないが，展開葉面積がやや小さくなる傾向にある. 根の生育はほとんど影響されなかった，乾物生産量は やや少なくなる傾问にあった，花茎発生に影響はみら れなかったが, 発生時期が早くなる傾向がみられた。 また葉や根などに久乏症状は発現しなかった。

4.Ca 欠之は生育や花茎発生に顕著な影響は現れな かった，また欠そ症とみられる症状は発現しなかった。 5. $\mathrm{Mg}$ 欠乏では, 展開葉数がやや少なくなる他は展 開葉面積, 根の発育, 乾物生産ともに完全培養区に遜 色なかった，花菱発生率には差がみられないが，花茎 発生時期が明らかに遅くなる。また特に欠乏症状は発 現しなかった。

\section{引用文献}

段 建雄・水田洋一・矢澤 進. 1993. 培地内の Ca 濃度が in vitro 培坫におけるファレノプシス実生 苗の生長に及ぼす影響. 園学雑. 62（別 2) 518-519.

遠藤宗男・杉 義人. 1992. 養液栽培ファレノプシス の 1 年間の生育及び養分吸収の推移. 園学雑. 61 (別 2) : 532-533.

Hinnen, M. G. J., R. L. M. Pierik and F. B. F. Bronsema. 1989. The influence of macronutritions and some 
other factors on growth of Phalaenopsis hybrid seedlings in vitro. Sci. Hort. $41: 105-116$.

位田晴久・橋本りつ子・田中豊秀. 1995, 施肥濃度な らびに頻度がファレノプシスの生長，開花に及ぼ す影響. 園学雑. 64 (別 1) : 40-41.

篗田 聡・深井忠進・米田和夫. 1990.ファレノプシ スの生育並びに盖分吸収に及ぼす施肥の影響. 園 学雑. 59 (別 2)：688-689.

Kubota, S. and K. Yoneda. 1993. Chemical components of Phaloenopsis at various phenological growth stages. Bull. Coll. Agr. \& Vet. Med., Nihon Univ. $50: 7-10$.

淮田 聡・米田和夫. 1993 a.コチョウランの生育・ 開花におよぼす窒素施用時期の影䇾。熱带農業 $38: 73-77$.

寉田 聡・米田和夫. 1993 b. ファレノプシスの生育 におよぼす施肥ならびにミズゴケと素焼鉢の理化 学性の影短. 園学雑. $62: 601-609$.

窪田 聡. 1994.ファレノプシスの安定生産に関する 植物栄養生理学的研究. 日本大学学位論文.

Poole, H. A. and J. G. Seeley. 1978. Nitrogen, potassium and magnesium nutrition of three orchid genera. J. Amer. Soc. Hort. Sci. $103: 485-488$.

Sheehan, T. J. 1961. Effects of nutrition and potting media on growth and flowering of certain epiphytic orchids. Amer. Orchid Soc. Bull, $30: 289-292$.

嶋田典司. 1989。培地の $\mathrm{K}, \mathrm{Ca}, \mathrm{Mg}$ のバランスと植物 の生長，作物の $\mathrm{K}, \mathrm{Ca}, \mathrm{Mg}$ 欠之と過剩. p. 67-71
日本土壤肥料学会編. 養液栽培と植物栄養. 博友 社. 東京.

須藤憲一・篠田浩一．1990．ランの栽培培地の羑水分 状態におよぼす雚水施肥方法の影䇾。野菜茶業試 花き部研究年報 $3: 60-63$.

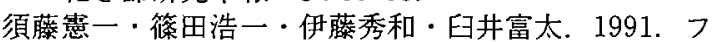
アレノプシスの生青に及ぼす灌水施肥方法の影㗜. 園学雑. 60 (別 1) : 524-525.

鈴木美国・米田和夫. 1994.フラスコ内ファレノプシ ス苗の生育ならびに養分吸収に及ぼす $\mathrm{NH}_{4}-\mathrm{N}$ : $\mathrm{NO}_{3}-\mathrm{N}$ 比の影響. 園学雑. 63 (別 1) : 520-521.

鈴木美国. 1995.フォレノプシス健苗生産における環 境要因に関する研究。日本大学修士論文.

田中豊秀・枡田正治・楮本亮治・茶谷正孝. 1986。絰 素形態，施肥時期がファレノプシスの生育と開花 に及ぼす影響並びに施肥窒素の花茎への寄与率. 園学要旨 昭 61 秋: 410-411.

田中豊秀・井上伸之．1987。ファレノプシスの生長に 及ほすリン濃度の影響。園学要旨. 昭 62 秋： 554-555.

田中豊秀・松野孝敏・枡田正治・五味 清. 1988. フ フレノプシスの生長と化学組成に及ぼす培盖液濃 度と培養土の影篦. 園学雑. $57: 78-84$.

米田和夫 · 上野俊士 - 佐々木弘康 - 内村忠久. 1984 . 施肥の打ち切り時期ならびに株龄の差異がファレ ノプシスの開花に及ぼす影望。園学要旨. 昭 59 秋 : 350-351. 